\title{
Online Kanal Yöneticisiyle Otel Oda Fiyatlandırmada Verim Yönetimi
}

\section{Yield Management in Hotel Room Pricing With Online Channel Manager}

Doç. Dr. Alpaslan ATEŞ

İskenderun Teknik Üniversitesi

Turizm Fakültesi

E-posta: alpaslan.ates@iste.edu.tr
Öğr. Gör. Murat YURTLU

İskenderun Teknik Üniversitesi

Turizm Fakültesi

E-posta: murat.yurtlu@iste.edu.tr

Öz

Otelcilik sektöründe pazarlama dağıtım kanallarında teknoloji kullanımı her geçen gün hızla artmaktadır. Verim yönetimiyle gelirleri artırmaya yönelik teknolojik uygulamalardan birisi de kanal yöneticisi yazılımlarıdır. Kanal yöneticisi yazılımlarının otellere avantaj sağlayıp sağlamadığının incelendiği bu çalışmada, sektörün pazarlama dağıtım yapısında çevrimiçi karmaşık yapısını etkin kontrol ile sağlayarak, zaman kazandırıcı özelliğinin operasyonel faaliyetlerine ve gelirlerine katkısı araştırılmıştır. İşletmeler kritik ve etkin dinamik fiyatlamalar yaparak, mevcut kapasitelerinde tam verimli bir doluluğa ulaşabilmektedir. Otellerin zaman zaman çevrimiçi pazarlama dağıtım kanallarında olumsuz durumlarla karşılaştıkları görülmektedir. Bu amaçla nitel araştırma yöntemi kullanılmış olup ikincil veriler ve sektörden örnek olaylar literatür tarama yapılarak ele alınmış ve işletme faaliyetlerine olabilecek etkileri belirlenmiştir. Çalışmanın sonucunda kanal yöneticisi yazılımlarının otel satış dağıtım sisteminde yararlı olabileceği saptanmıştır.

Anahtar Kelimeler: Online satışlar, e-ticaret, fiyatlandırma, gelir yönetimi

\section{Abstract}

The technology's usage is increasing day by day in marketing distribution channels in the hospitality firms. The channel manager software is one of the application of the technology to efficiently improve the revenue in hotel marketing distribution channels. In this study, which examines whether the channel manager software is advantageous for the hotels and the online complex structure in the distribution channels by providing with effective control for the time saving and dynamic pricing contribution to operational activities. Hoteliers can achieve their full capacity with full efficiency by making critical and efficient dynamic pricing. It is seen that the hotels meet with negative factors especially in the processing of e-commerce sales marketing. In the study, secondary data and case studies were analyzed by literature review and the effects that could be attributed to business activities were determined.

Key Words: Online sales, e-commerce, pricing, revenue management 


\section{Giriş}

Otel işletmelerinin en mühim rekabet öğelerinden birisi olan dağıtım kanalları sistemi, birçok turizm tedarikçisi ile bireysel müşteriler ya da müşteriler ile oteller arasında bir köprü bağı görevi görmektedir. Otellerin ürün ve hizmetlerinin pazarlanmasında uluslararası farklılık gösteren çoklu dağıtım kanallarının kullanılması önemlidir. Bu durum pazarlama dağıtım sisteminin karmaşık ve çok yönlü bir yapıda olmasını sağlamaktadır (Yıldız ve Yıldız, 2015). Günümüzde, otelcilik sektöründe yer alan çoğu firma, rekabetin yükselmesinden dolayı varlıklarını sürdürebilmek ve kazançlarını en üst düzeye taşımak için teknolojik pazarlama tekniklerini operasyonel faaliyetlerinde kesintisiz kullanabilme tekniğiyle harmanlamak durumunda kalmışlardır (Breffini ve diğ. 2017).

Verim yönetimi uzun zamandır otelcilik sektöründe gelirlerin artırılması için başvurulan kritik programlardan biridir. Gelir yönetimi veya getiri yönetimi ismiyle adlandırılmakta olan verim yönetimi kapasitesi sınırlı ürünü, kısıtlı süreçte, doğru müşteriye, uygun zamanda, uygun olan fiyattan satarak; kârı en üst düzeye çıkarabilme kabiliyeti olarak tanımlanabilir (Meterrelliyöz ve Tan, 2014).

$\mathrm{Bu}$ çalışmada online satış kanallarının yönetimi için tercih edilen kanal yöneticisinin, otel işletmelerinin fiyatlarını ve oda müsaitliklerini yönetmede ne derecede verimli ve etkin kullanılabileceğini ölçebilmek amacıyla literatür taraması ve sektörden örnek durumlar incelenerek elde edilen verilerin, uygulamada sorunlara karşı oda satışlarında pazarlama intiyaçlarını karşılayabilmesi düzeyinin saptanması amaçlanmaktadır.

Turizmde bulunan girişimcilerin çoğu, artış gösteren fiyat politikalarını aşabilmek, aradaki komisyonu minimize etmek için tüketicilerine direkt ulaşmayı ve pazarlama işleyişlerini kendi bünyelerinde organize etmeyi daha kazançlı bulmaktadırlar. Genelde oteller, seyahat acenteleri, yeme-içme ve eğlence tesisleri ile araç kiralama firmaları kendilerine özgü rezervasyon ve iletişim alt yapılarını kurarak kendi hedef kitlelerine ulaşmayı uygun bulmaktadırlar. Böylece internete olan talep hem üreticilere hem de tüketicilere sunduğu hız, uygun fiyat ve güvenlik gibi fırsatlar nedeniyle karşılıklı olarak artmakta hem de sektör ile internet arasındaki ilişki güçlenmektedir. Bunun sonucunda şirketler, limitli olarak verdikleri çevrimiçi hizmetleri günden güne geliştirip, çeşitlendirerek tüketicilerinin ihtiyaçlarına sunmaktadırlar(Ansen ve Fırat, 2009).

Otelcilik sektöründe son yıllarda işletmelerin bu güncel ihtiyaçlarını karşılamak üzere yeni bir yazılım sektörü ortaya çıkmıştır. Otelcilik sektöründe e-ticaret dağıtımı için çözümler sunan bu yazılım firmaları farkındalık yaratmak adına henüz konunun bilincinde olmayan işletmelere de kayıpları gelirleştirebilmeleri ve gelir maksimizasyonu sağlayabilmeleri adına eğitim seminerleri düzenlemektedirler. Bu eğitimlere işletme sahipleri, genel müdürler, satış ve pazarlama yöneticileri katılım göstermektedir. Fakat bu konu her ne kadar eğitimlerle desteklense de teknolojinin yeni olması ve başlangıçta karışık bir kuruluma sahip olması sebebiyle geleneksel otelcilik pazarlamasında bu dönüşüm hızlı olamamaktadır. Ayrıca işletmelerin de yeterince konunun önemini anlayamamalarından ürünü satın almış olsalar dahi etkin kullanamamaları söz konusu olabilmektedir. Bu araştırmanın amacı otelcilik sektöründe yeterli etkinliği görememiş olan bu yazılım sektörü ürününün farkındalığını ve hangi güncel intiyaçlara cevap verdiğini ortaya koymaktır. Buna bağlı olarak çok önemli unsurlardan olan fiyat (Murat ve Çelik, 2007) konusunda karşılaşılan güncel yanlış politikaların işletmede oluşturduğu kayıpları en aza indirgemeyi tespit edebilmek de amaçlar arasında yer almaktadır. 


\section{Literatür Araştırması}

Otellerde verim yönetimi ile ilgili ülkemizde ve yurtdışında araştırmalar bulunmasına rağmen, gelirin kaynağını oluşturan oda fiyatlamaları yönetimi ile ilgili çok az sayıda çalışmaya rastlanılmıştır.

Illişkisel tarama türünde yapılan bir araştırmada; ülkemizdeki otel işletmelerinin yönetim yapılarının internet tabanlı pazarlama operasyonları üzerinde etkinliği araştırılmıştır. Bunun belirlenebilmesi için işletme yönetimlerinde anket çalışması yapılmış ve bu veriler ışığında konaklama işletmelerinin, internet pazarlamasının gelecekteki durumunu görebilmesi ve gerekli önlemleri alarak internette pazarlamaya önem vermesi gerektiği ileri sürülmüştür. Aynı zamanda işletmelerin fonksiyonel internet sitelerinin geliştirilmesi için çaba harcamaları gerektiği ve kendi internet sitelerinde; fiyat, ürün, tutundurma ve dağıtıma yönelik özellikleri kesinlikle bulundurmaları gerektiği vurgulanmaktadır (Boylu ve Tuncer, 2008).

2010 yılında oda fiyatlamasının dağıtımda eşitlik ilkesini analiz eden bir başka araştırmada (Demirciftci ve diğ., 2010), otelin en iyi fiyat garantisi ile tanıtıma katıldığı çevrimiçi platformlarda bu sloganını sürdürebilmesinin aslında oldukça güç olduğu belirlenmiştir. Ayrıca otel işletmesinin mevcut dağıtım kanallarının kontrolü için ekstradan maliyetli çalışmalar yapmasının tüketicilerin güvenini kazanma konusunda şart olduğu tespit edilmiştir. Bunun için ilgili çalışmada günümüz Merkezi Rezervasyon Sistemi (Central Reservation System-CRS) bilişim ürünü olan, kanal yöneticilerinin faaliyeti kapsamına giren ve basitçe yönetilebilen Tek Ekrandan Kullanım (Single Image Inventory) tekniğine yatırım yapmaları gerektiği vurgulanmıştır.

2014 yılında yapılan başka bir çalışma kapsamında ise; statik değerlendirme yapılarak, zincir bir otelin günlük kapasite tahsis edilmesi sorunu ile ilgilenilmiştir. Otelin dinamik fiyatlama modelleri uygulaması, yani rezervasyon sürecinde oluşan talebi belli zamanlarla güncelleyerek aralıklarla belirlediği fiyatları satışa kapatıp açması ile daha etkin bir gelir yönetimi performansı sağlanabileceği tespit edilmiştir (Meterrelliyöz ve Tan, 2014). Fiyatları bir üst gruptan satma veya bir alt gruptan satma uygulamalarının otele gelir yönetiminde daha fazla avantajlar sağlayacağı ilgili çalışmada saptanmıştır. Günümüz şartlarında tüketicilerin seçimlerini model içine alan daha karmaşık, ama daha etkin sonuç ortaya çıkaran uygulamalar geliştirilmekte olduğu ve otelin bu konseptte bir modeli kullanmasının potansiyel geliri daha da yükseltebileceği yine bu çalışmada belirlenmiştir.

Turizm ürün pazarlamasına yönelik gelişen stratejilerin ve yön değiştiren pazarlama faaliyetlerinin incelendiği 2015 yılındaki başka bir araştırmada da, teknolojik değişimlerin çok hızlı gelişmesinden dolayı, bu değişime uymanın ve dinamik olmanın şart olduğu sonucu ortaya çıkmıştır. Turizmde bulunan dağıım kanallarının teknolojik gelişmelerle oluşan değişim, olumlu algılanmalı ve tur operatörleri ile seyahat acenteleri bu değişim dalgasıyla kendilerini buna adapte edip, geliştirmeleri gerektiği ve teknolojiyle uyumlu olarak daha güçlü hale gelmek için tüm olasılıkları dikkate almalarının kaçınılmaz olduğu anlaşılmaktadır. Bütün bu gelişmelerin ışığında, sektörün en önemlilerinden olan geleneksel seyahat acenteleri ve tur operatörlerinin gücünün sarsılıyor olduğu ve bunun günden güne artacağını görerek ivedilikle önlem almalarının gerektiğinin ve hizmetlerinde dönüşüme gitmelerinin önemli olduğu sonucu ortaya çıkmıştır. Ayrıca bu değişme sürecinde dikkate alınması gereken diğer unsur "yeni turist" kavramıdır. Bu kavram araştırmacı, farklı ve yeni tecrübeler kazanmayı dileyen, "bekle, gör" düşüncesiyle hareket ederek daha uygun fiyatlı bir turu oluşturmaya istekli bir düşünceye sahiptir. Tur operatörleri ve seyahat acentelerinin bu 
yeni kavramın isteklerini etkin analiz etmesi, hizmetlerini bu yönde ilaveler yaparak güncellemesi önem arz etmektedir. Bu doğrultuda seyahat işletmelerinin bu "yeni turisti"in beklentilerini karşılayacak yaklaşımlar oluşturup uygulaması da çok önemlidir (Bohur ve Eryılmaz Kirali, 2015).

İnternette otelcilik ürün pazarlaması konusunda bilgisayar ve mobil cihazların işletme tanıtımlarının ele alındığı 2015 yılındaki bir araştırmada ise, otel işletmesi yönetiminin online işlevsellik ve dev online seyahat acentelerinin önünde yer alabilmesi için gerekli ürün yerleştirme örnekleri ele alınmıştır. Araştırmada otel işletmelerinin kendi web sitelerini bilgisayar ortamındaki gibi mobil cihazlar üzerinde de gerekli uyumlulukları sağlamalarının kaçınılmaz olduğu tespit edilerek mobil platformların müşterilerine ulaşmada zaman ve etkinlik konusunda büyük olanaklar kazandırdığı belirlenmiştir (Murphy ve diğ., 2016).

İnternet, turizm pazarlama karmasının tüm unsurları açısından çok güçlü bir araç olarak kabul edilmektedir (Roland ve diğ., 2013). Günümüz rekabet ortamında otel gelir yöneticileri, oda müsaitlik ve fiyatlarını mümkün olduğunca geniş bir kitleye ulaştırabilmek amacıyla sahip oldukları kontratlı seyahat acenteleri ve tur operatörlerinin yanında, internet teknolojisi ile birlikte gelişim gösteren expedia, booking, orbitz, hrs.de vb. internet seyahat acentelerine de intiyaç duymaktadırlar (Christodoulidou ve diğ., 2007). Ayrıca son yıllarda otellerin kendi web siteleri, yalnızca ürün veya hizmetlerini tanıtmakla kalmayıp aynı zamanda daha çok tüketiciyi hedef seçerek, otellerin kendi rezervasyon sistemlerini kullanarak gelirlerini arttırabildikleri bir ortam haline gelmiştir (Ateş ve Boz, 2015).

Fiyat, bir otelin pazarlama karması elemanlarının en önemlilerinden olup, birçok bilim insanı fiyatlama ve fiyat stratejisinin önemini, sürdürülebilir rekabet üstünlüğü oluşturmak için bir temel olarak tespit etmektedirler (Ivanov, 2014). Otel gelir yönetiminde çok önemli yeri olan fiyatlama kontrolünün bu gelişen dağıtım sistemlerinde zaman ve etkinlik açısından kanal yöneticisi tarafından sağlanması büyük önem arz etmektedir. Kanal yöneticisi, otel işletmelerinin kendi web sitesi dahil tüm B2C (Business to Consumer) satış kanallarında fiyat ve kontenjanlarını tek bir panel (extranet) üzerinden kontrol ederek, işletmelere zaman ve verimlilik kazandıran bilgisayar yazılımıdır (Linkage, 2017).

Otel işletmeleri birer ticari işletme olmakla birlikte, bazı özellikleri nedeni ile diğer ticari işletmelerden farklııı gösterdiğinden, fiyatlandırma kararının verilmesinde konaklama işletmelerinin taşıdığı farklıııklara dikkat etmek gerekmektedir. Bu farklılıklardan en önemlisi turistlerin satın alma kararını, mal ve hizmeti görmeden satın almasıdır (Demirtaş, 2010). Zaten soyut anlamda önceden satın alınan zaman, üreticinin sağladığı güven ile doğru orantılıdır. Turistlerin, önceden görerek değerlendirme imkanı olmadan satın almaları gereken konaklama hizmetleri için yüksek fiyat, hizmet kalitesini belirleyen bir gösterge niteliği taşıyabilmektedir. Fiyatın yüksek olmasına rağmen, satın alınan hizmet kalitesi beklenenden düşük olursa tüketici memnun kalmayabilmektedir (Murat ve Çelik, 2007). Ayrıca kalite ve fiyat uygunluğu otelin imajı açısından belirleyici özelliktedir. Bu nedenle otel işletmelerinin bir oda için belirleyecekleri fiyatın ürün ile eş değerliliği önemli olabilmektedir. Eğer fiyat ve değer boyutu tüketiciler gözünde uygun ise, konaklama işletmesinin uzun vadede doluluk oranı yükselecek ve pazar payı artabilecektir (Çıvak ve diğ., 2017).

Konaklama işletmelerinin günümüzde yönetim işleyişinin önemli bir parçası olan verim yönetimiyle gelirlerin idaresi hizmetin doğru fiyattan, doğru zamanda, doğru tüketicilere ve doğru kanaldan ulaşabilmesini sağlayan satış pazarlama anlayışıdır (Çıvak ve diğ. 2017). Otelcilik sektöründe oda gelirlerinde Verim Yönetimi (Yield 
Management) ileride afişe fiyattan satışı sağlanabilecek bir odayı şimdiden indirimli şirket fiyatından satmayarak, ayrıca yine ileriki bir tarihte afişe fiyatıyla boş kalabilecek odaların etkin tahminlemeyle şimdiki zamanda indirimli satışını gerçekleştirerek maksimum doluluğu sağlayabilmektir (Çelebi, 2017). Otellerin satış pazarlama birimleri uygulanan aksiyonları, özel indirim dönemlerini ve büyük seyahat acentelerinin kampanya tarihlerini etkin takip ederek, diğer taraftan resmi tatil ile bayram dönemlerini de dikkate alarak geleceğe yönelik doğru tahminlemeler ve buna bağlı fiyat politikaları belirlemelidir.

\section{Yöntem}

Otellerin oda satışlarında internet üzerinden verim yönetim stratejilerini kullanarak gelir etkinliğine ulaşabilmeleri üzerinde yapılan araştırmalar ışığında, otelcilik sektöründe verim yönetiminin işletme gelirlerini arttırmada ve işletme kabiliyetlerinin en üst etkinlikle kullanılabilmesinde çok önemli bir role sahip olduğu anlaşılmaktadır. Literatüre bakıldığında özellikle ülkemizde konaklama işletmelerinin dinamik fiyat kontrol mekanizmasının yeteri kadar geliştirilememiş olması sebebiyle maksimum karlılığa yönelik araştırmalara rastlanılamamaktadır. Bu çalışmada benzer çalışmalar baz alınarak konuya ilişkin gözleme dayalı örnek durumlar ve ikincil veriler referansında, otel doluluklarının etkin bir biçimde kullanılabilmesine yönelik verimli oda kapasitesinin etkin bir biçimde sürdürülebilmesi gereklilikleri ele alınmaktadır. Ayrıca çalışmada internetten makale, belge, kitap, tez, bildiri vb. eserlerden verilerin taranmasıyla ikincil bilgiler toplanarak literatür araştırması yapılmıştır. Çalışma kapsamında geleneksel anlamda ele alınan pazarlama karması unsurları ve fiyatlandırma boyutlarının yanında gelişen e-ticaret olanaklarının çeşitlenmesi ve etkileşimleri örneklerle açıklanmıştır.

\section{Turizm Pazarlaması ve Fiyat}

Turizm sektöründe üretimin özellikle soyut anlamda gerçekleşmesi ürün, fiyat, satış yeri ve tutundurmadan (4P) oluşan geleneksel pazarlama karmasına üç temel yapı taşı olan hedef kitle, süreç ve fiziksel kanıt olarak ilave edilmesini gerekli kılarak turizm pazarlama karmasını (7P) oluşturmaktadır. Otel işletmelerinde hizmet pazarlaması yalnızca 7P değil 7C ile birlikte ele alınmaktadır (Öztürk, 2017). Başarılı etkin bir hizmet üretim süreci için gerekli olan bu karma aşağıda üretici ve tüketici yönlü 7P ve 7C olarak tablo 1'de belirtilmiştir.

Tablo 1: Üretici ve Tüketici Yönlü Pazarlama Karması

\begin{tabular}{|l|l|}
\hline 7P & 7C \\
\hline Ürün (Product) & Müşteri Değeri (Customer Value) \\
\hline Fiyat (Price) & Maliyet (Cost) \\
\hline Yer (Place) & Erişilebilirlik (Convenience) \\
\hline Tutundurma (Promotion) & Müşteri İletişimi (Communication) \\
\hline İnsan (People) & Önemseme (Consideration) \\
\hline Fiziksel Belirti (Physical Evidence) & Onaylama (Confirmation) \\
\hline Süreç (Process) & Eş güdüm (Coordination) \\
\hline
\end{tabular}

Kaynak: (Altunışık, 2009)

Tablo 1'de de görüldüğü üzere otel işletmelerinde pazarlama karması üretici ve tüketici arasında etkileşimli bir bağ bulunduğunu göstermektedir. Chu (2001)'e göre müşteriler, gelişen seçici tavırlardan dolayı, en uygun fiyatta ve en hızlı zaman zarfında teslim alabilecekleri hizmetlerden meydana gelen etkin bileşeni seçmektedirler. Bu sebeple giderek artan sayıda müşteriler geleneksel dağıtım kanallarını es geçerek 
rezervasyonlarını direkt otellere yapabilmektedir. İşletme yönetimleri de, direkt yapılan rezervasyonlara daha çok ilgi ve önem vermekte ve müşterilere en iyi fiyat garantisi uygulayarak dikkat çekmektedirler (Bayram ve Yaylı, 2009).

\section{Otel İşletmelerinde Oda Fiyatlaması}

Fiyat, şirketi hedeflerine ulaştırması bakımından önem arz ettiği gibi pazarlama bakımından da oldukça önemlidir. Fiyat oluşturulurken, talep göz önünde tutularak oluşturulacak fiyatın tavanıyla birlikte maliyetler hesaba alınarak belirlenecek fiyatın tabanı bir limit meydana getirmektedir. Bunun yanında işletmeler, fiyat geliştirirken maliyetleriyle birlikte şirket hedeflerini göz önünde bulundurmalıdırlar. Burada rekabetçi unsurlar fiyat tabanının azalmasına sebebiyet vermektedir. Bu ifadelerden yol çıkarak doğru ve tek bir stratejinin olamayacağı, çeşitli modellerde fiyatlama oluşturulabileceği görülmektedir. Hizmetler husunda fiyatlama stratejileri maliyete dayalı fiyatlama, talebe dayalı fiyatlama ve rekabete dayalı fiyatlama şeklindedir (Binbay, 2007).

Maliyete dayalı fiyatlamada fiyatı oluşturan unsurlar doğrudan maliyetler, genel üretim maliyetleri ve kar marjı şeklindedir. Genelde şirketler tarafından fiyatlamada tercih edilen geleneksel fiyatlama "maliyet artı" yöntemidir. Burada ilk olarak, üretimin maliyeti tespit edilir, sonrasında bu maliyete bir kar payı katılarak pazar fiyatı oluşturulur. Maliyete ilişkin verilerin güvenilir ve sağlam olabilmesi için şirkette etkin ele alınmış bir maliyet hesaplamasının olması gerekmektedir. Maliyet artı yönteminde ele alınacak esas maliyet miktarları maliyetleme de temel gösterilen çerçeveye göre değişken ve tam maliyet miktarları olabilmektedir. Değişken maliyete göre belirlenecek fiyat değişken faaliyet giderleri, değişken üretim maliyeti ve kâr payının toplamından meydana gelen katkı payı temelli fiyatlandırmayı oluşturmaktadır (Badem ve Fırat, 2011). Tam maliyete göre belirlenecek fiyat genel üretim maliyeti, faaliyet maliyetleri ve kâr payının toplamından oluşur. Üretimi hizmet olan turizm işletmelerinin birim başı maliyeti etkin olarak hesaplayabilmesi mal üretimindeki gibi basit olmadığından hizmet maliyetinde ölçülebilen çıktılardan ziyade girdi birimleriyle fiyatlandırma yapılabilmektedir (Binbay, 2007).

Talebe dayalı fiyatın belirlendiği ve değiştirildiği fiyatlandırma modelindeki talep, çalışma konumuz olan otellerde gelir yönetiminde önem arz eden bir unsurdur. Bu fiyatlamada, ürünün talep edilirliğine göre hizmetler fiyatlandırılmaktadır. İşletmenin üretimi hizmet sunulduğu zamana bağlı olarak pazarda çok talep görüyorsa, ürünün fiyatı yükseltilir; talep beklenenden az ise daha düşük fiyatlamayla indirimler uygulanır. $\mathrm{Bu}$ yönteme göre üzerinde durulan kısım etkin fiyat seviyeleri kullanarak farklı fiyatlarda talebin ne olacağını ön görebilmektir. Özetle en çok toplam geliri sağlayacak fiyat seçilebilir. Belirli bir hizmetin pazarlanmasında, birden fazla fiyat kullanılması istendiğinde, fiyat farklılaştırması ortaya çıkmakta ve tüketicilerin türü, dağıtım kanalının çeşidi ve satın alma zamanları dikkate alınarak ürünün fiyatı farklılaştırıır, aynı hizmet ürününe farklı anlarda farklı fiyatlar uygulanır (Öndoğan, 2017). Otel odalarının tıpkı uçak koltuklarında olduğu gibi doluluğa göre fiyatlama yapması ileriki yıllarda kaçınılmaz görülmektedir (Meterrelliyöz ve Tan, 2014). Verim yönetimi stratejisinde başarı, tüketici isteklerinin etkili bir biçimde kontrol edilmesine dayanmaktadır. Bu kontrol fiyatlandırmaya bağlı olarak turistlerin kalış süresinin etkili ve geçerli tahmin edilmesiyle yapılabilmektedir. Fiyatlar her tüketici için sabitlenebilir veya farklı zamanlarda farklı kişilere değişik fiyatlar uygulanabilir. Etkin bir oda gelir yönetimi için otel yöneticilerinin deneyimlerine dayanarak konaklama süresi karakteristiğinin farklı pazar destinasyonlarında çok iyi tahminlenmesi gerekmektedir. Bu tahminleme, gelecek dönemler için fiyatların doğru bir şekilde belirlenmesinde önemli bir rol üstlenecektir. Doğru tahminleme için oteller otelcilik paket 
programlarından (PMS: Property Management System; Fidelio, Elektra, Sedna vb.) faydalanmaktadırlar. Paket programlarının geçerli sonuçlar verebilmesi için pazar bölümlerine göre kalış sürelerini, fiyat kategorilerini ve otele giriş çıkış tarihlerini içeren müşteri istatistik kayıtlarına ihtiyaç duyulmaktadır (Çıvak, 2016). Özellikle şehir merkezi otellerinde yüksek verimli satışların ve etkin doluluğun ardında başarılı doluluk tahminlemeye bağlı olarak gerçekleştirilen operasyonel fiyatlamanın önemi yüksek olabilmektedir.

Rekabete dayalı fiyatlandırmada fiyat belirlenirken rakip işletmelerin fiyatlarını göz önünde bulundurmak önemlidir. Bazı durum ve bölgelerde tamamiyle rekabete dayalı oluşturulan fiyatlama politikalarında, rakiplerin fiyatı şirketler için giderlerinden ve gelirlerinden daha önemli bir boyuta gelebilmektedir. Bu yöntemde fiyatlama oluşturulurken, rakiplerin fiyatlarıyla eşit fiyatlar uygulanması tercih edilmeyip otel işletmesinin kendine has pazarlama stratejilerine bağlı olarak rakiplerin biraz daha üzerinde veya altında fakat yakın değerlerde fiyatlar belirlenerek fiyatlamalar yapılmaktadır (Binbay, 2007). Fiyat çeşitliliğine talebin duyarlıığı tahmini oluşturur ve bu tahminin kesin yapılamaması belirsizliğe sebebiyet verebilir. Bunun sebebi fiyatın, hizmeti üreterek sunan ile hizmetin kurumsal veya bireysel tüketicileri arasında oluşan pazarlık çekişmesidir. Özellikle rakipler için pazar dalgalanmaları ve koşulları hedef fiyatın oluşmasında etkili olacaktır. Maliyet fonksiyonları ve yapısı, talep karlılığına ve fonksiyonuna ilişkin geçerli bilgiler nezdinde fiyatlama kurallarının kısıtlayıcıları olarak ortaya çıkabilmektedir. Fiyatlama yöntemleri rakipleri ölçüt alarak, şirketin varlığını devam ettirebilmek için il olarak maliyetleri karşılayacak miktarı, departman karlılığını ve süreklilik için belirsiz durumları indirgemekte kullanılmaktadır. Hesaplamaların gerçek hedefi departman kârlılığını sürdürerek verimli artış oluşturabilmektedir (Yıldıztekin, 2009). Fiyat, rekabetçi pazara göre ayarlanmaktadır. Rekabet eden ürün homojense ve ürünün fiyatı pazarda geçerli en önemli unsur ise, bu strateji kullanılmaktadır. Önemli olan ürün fiyatını sadece maliyete veya talebe bağlı tutmamaktır. Şirketlerin maliyetleri veya hizmetine olan talepleri dönemsel farklılaşabilir, ancak rakip şirketler fiyatlarını değiştirmediği müddetçe fiyatta değişiklikler yapılmamaya özen gösterilmektedir. Talep veya maliyet değişmese de, rakip şirketler fiyatı değiştirirse, fiyat değişikliğine gidilmektedir (Erdem, 2007).

Günümüz teknolojisindeki gelişmelerle beraber zaman olgusu önemini günden güne arttırmaktadır. Otelcilik sektöründe özellikle üretilen ürünün zaman olduğu düşünülürse, başarılı otel faaliyetlerinin teknolojiden yoksun olması düşünülmemelidir. Kanal yöneticisi (Channel Manager) yazılımlarının sunduğu özellikle rekabete dayalı fiyatlama modeli için geliştirilmiş çözümlerden birisi de fiyat takip yönetimi ürünüdür. Bu ürün kullanımda rate shopper, compare manager gibi isimlerle de sektörde kullanılmaktadır. Rakiplerin fiyatlarını analiz ederek rakip otellerin fiyat değişimlerini anlık olarak yönetime sunabilmesine olanak sağlamakta olan fiyat takipçisi yazılımı, bu veriler ışığında otel yönetiminin kendi doluluğu ve rakip fiyatlarını birleştirerek en doğru ve etkili fiyatı kısa zaman zarfında uygulayabilmesini sağlamaktadır.

\section{Otellerde Dağıtım Kanalları ve Pazarlama Teknolojileri}

Turizm sektöründe faaliyette olan konaklama işletmeleri, rekabetin sürekli geliştiği bir ortamda benliklerini geliştirebilmek için mevcut potansiyel tüketicilerine ürettikleri ürünleri etkin ve daimi bir şekilde tanıtmak mecburiyetindedirler. Konaklama işletmelerinin bu işleyişleri oluşturmasında web yoluyla pazarlama, etkin bir araç olarak görev almaktadır. Ayrıca web, otel ürün pazarlama faaliyetlerinde yeni olanaklar da sunmaktadır (Bayram ve Yaylı, 2009). Tüketicilerin, konaklama tesislerinin internet sitelerini kullanma sebepleri arasında fiyat ve zaman başlıca iki temel unsur olarak 
görülmektedir. Tüketiciler interneti yoluyla ürünler hakkında daha detaylı bilgiye hızlıca erişebilmekte ve fiyatlar arası karşılaştırmaları görebilmektedirler (Özdipçiner, 2010).

Turizm sektöründe diğer sektörlerde olduğu gibi yaygın olarak kullanılmakta olan elektronik ticaret yöntemleri; İşletmeden-İşletmeye (B2B), İşletmeden-Tüketiciye (B2C), Tüketiciden-Iş̧letmeye (C2B) ve Tüketiciden-Tüketiciye (C2C) olmak üzere dörde ayrılmaktadır. Bu uygulamalar ile ilgili bilgiler Tablo 2'de yer almaktadır.

Tablo 2: Turizm Sektöründe Elektronik Ticaret Uygulamaları

\begin{tabular}{|c|c|c|}
\hline $\begin{array}{c}\text { Elektronik Ticaret } \\
\text { Uygulamaları }\end{array}$ & $\begin{array}{c}\text { Turizm } \\
\text { Işletmesi }\end{array}$ & Tüketici \\
\hline $\begin{array}{c}\text { Turizm } \\
\text { Işletmesi }\end{array}$ & $\begin{array}{c}\text { B2B } \\
\text { Oteller, tur operatörleri, seyahat } \\
\text { acenteleri ve turizmle ilgili diğer } \\
\text { işletmelerin birbirleriyle olan e- } \\
\text { ticaret ilişkisi. }\end{array}$ & $\begin{array}{c}\text { B2C } \\
\text { Tüketicilerle, } \\
\text { oteller, tur operatörleri ve } \\
\text { seyahat acenteleri arasındaki } \\
\text { e-ticaret ilişkisi. }\end{array}$ \\
\hline Tüketici & $\begin{array}{c}\text { C2B } \\
\text { Tüketicilerin teklif ve } \\
\text { ônerilerini, turizm işletmeleri ile } \\
\text { paylaşmaları sonucu oluşan e- } \\
\text { ticaret. }\end{array}$ & $\begin{array}{c}\text { C2C } \\
\text { Müşterilerin, turistik işletmeler } \\
\text { hakkındaki görüslerini } \\
\text { birbirleriyle paylaşmaları ve bu } \\
\text { bilgilerin satışıncu oluşan } \\
\text { e-ticaret. }\end{array}$ \\
\hline
\end{tabular}

Kaynak: (Çavuşoğlu, 2010)

\subsection{Turizm Sektöründe B2B (Business to Business) Ticaret Uygulamaları}

Otelcilikte B2B model ticaret denilince paket tur satışlar söz konusu olmaktadır, başka bir ifadeyle oteller ile tur operatörleri ve seyahat acenteleri arasında sezonluk-yıllık kontratlı net fiyat üzerinden yapılan kontenjan sözleşmeleridir (Özdemir, 2011). Sözleşmede yer alan net fiyatlara tur operatörleri ile seyahat acenteleri belirlemiş oldukları oranlarda "Mark-up" olarak ifade edilen komisyonlarını \%15 ila \%40 oranlarında ilave ederek uçak ve transfer dahil gibi paketler oluşturup son tüketiciye pazarlamaktadırlar (Çelebi, 2017). Tüketiciler giydirilmiş bu fiyatlarda otelin satış fiyatını görememektedirler. Paket halinde tatilini satın almaktadırlar ve konaklamalarını geçirmektedirler. B2B model turizm ticareti, özellikle tatil destinasyonları için en büyük hacimli, uzun süre konaklamalı kitle rezervasyon satışlarının gerçekleştiği uygulamalardır. Özellikle 4 yıldızı ve 5 yıldızlı oteller ile 1. sınıf tatil köyleri başta olmak üzere, bölge otellerinin normal şartlarda yüksek oranlara varan doluluklarını oluşturabilmektedir (Sarışık ve Akova, 2006). Otel işletmeleri için hayati derecede önemli olan B2B ticaret modeliyle oteller dağıtım kanallarında çok geniş alanlarda varlığını büyük tur operatörlerinin (Whole Saler; Thomas Cook, Hotel Beds, FTI, GTA, Travco vb.) web sayfaları, katalogları vb. gibi mecralarında yayarak saygınlıklarını da arttırmaktadır ve bunun sürekliliğinin çabası içerisindedirler (Kethüda ve Faikoğlu, 2017).

B2B e-ticaretin, turizm işletmelerine sağladığı avantajları aşağıda özetle sıralamak mümkündür (Çavuşoğlu, 2010).

- Şirketin sabit maliyetlerinin azalmasıyla birlikte verimliliğini arttırır.

- Bürokrasiyi azaltır.

- İletişim giderlerini ve stoklama maliyetlerini azaltır.

- Sürdürülebilir evrensel rekabet avantajı sağlar. 
- Hizmet kalitesini artırır ve sürekli aktif iş yapabilme olanağı sağlar.

- Evrensel işbirliği imkânlarıyla, turizm şirketlerinin bölgesel ekonomik zorluklardan en az zararla çıkabilmesini sağlar.

- Yanlışların azaltılmasında yararlıdır.

- Turizm firmalarının, hedef tüketicilere daha kolay zamanda erişebilmesini sağlar.

- İşletmeler arasındaki işleyişin daha hızlı, daha kolay ve daha az maliyetle oluşturulmasına imkan yaratır.

- Araştırma geliştirme çalışmalarının artmasını sağlar.

\subsubsection{B2B Ticarete Dayalı Oda Satış Gelirleri}

Fiyat kavramı diğer hizmet sektörlerinde olduğu gibi otelcilikte de en ön sıralarda yer almaktadır. Trip Advisor sitesinin 2016 yılında tatilciler arasında yaptığı araştırmada, tatil seçiminde en önemli kriterin fiyat olduğu \%93 gibi bir oranla turistler tarafından yapılan ankette belirlenmiştir (Global Report, 2016).

Her ürünün prestijine bağı olarak talep gördüğü bir değeri söz konusudur. Otelcilikte bu değeri belirleyen ürünün kalitesiyle birlikte diğer önemli bir unsur zamandır. Sezona göre fiyatlarda azalış ve artışlar, geleneksel otelciliğin her yeni dönemde uyguladığı B2B kontratlarda yerini alır. Ayrıca bu dönemler düzenlenirken sadece mevsimsel özellikler değil ulusal ve diğer ulusların resmi tatilleri de dikkate alınmaktadır. Günümüzde ise kolaylaşan seyahat imkanları sayesinde ulusal ve uluslararası çeşitli kongreler, fuarlar ve organizasyonlar hem ulusal hem de uluslararası boyutta artış göstermektedir. Fiyatlamalar yapılırken özellikle bu takvimlere dikkat etmek büyük önem teşkil etmektedir (Yenidoğan ve Yenidoğan, 2013). Çünkü gözden kaçabilen özel gün ve haftalarda oteller tam doluluklara düşük fiyatlarla erişebilirken, boş kalan günlerde de gereğinden yüksek fiyatlarla satışa çıkmış olabilmektedirler.

Otelcilikte satış pazarlamada kazançlar kolay bir biçimde tespit edilirken, kayıplar da bunun aksine tam tespit edilemeyebilmektedir. Başka bir ifadeyle otele rezervasyon yapmayan bir potansiyel tüketiciyi otel asla bilememektedir. Oteller doluluk beklentilerini çok iyi analiz etmeli ve buna bağlı etkin fiyatları oluşturabilmelidirler. Otel işletmelerinin gelirlerini oluşturan en önemli kalemlerin başında oda gelirleri gelmektedir. Bu sebeple oteller satışı gerçekleştirilmiş odaların gelirlerini etkin bir biçimde elde edebilmesi ve muhasebeleştirerek gelirleştirebilmesi ekonomik güçleri açısından önemlidir. Bu durumu örnekle açıklamak gerekirse, B2B kontratlarda genelde acentelerin otellere gerçekleşen konaklama ödemeleri, müşterilerin otelden ayrıldıktan sonra taraflarına otelden gönderilen faturalama karşılığında yapılmaktadır. Faturaların otelden acenteye belirli kontrollerden sonra gönderilerek belli bir zamana intiyaç duyuluyor olması, acentelerin genelde her ayın belirli günlerinde ödemeleri toplu yapıyor olmaları, sık sık hatalı faturalandırmalarla sürecin uzaması ve hatta acentelerin bazı dönemlerde ödeme güçlüklerine düşmesi gibi zaman alıcı durumlar meydana gelebilmektedir. Her ne kadar B2B kontratlar güvenilir tur operatörleri ve seyahat acenteleri ile yapılıyor olsa da (Yenidoğan ve Yenidoğan, 2013) zaman zaman yaşanan iflaslar da işi daha da zora sokabilmektedir (Yakut Aymankuy, 2001). B2B kontratların oteller tarafından vazgeçilmez sebeplerinden, acentelerin otelleri yüksek oranlarda doluluklara ulaştırabilme yetenekleri ve pazarlamadaki güçlü işlevleri sayesinde bu durum genelde otelciler cephesinde, ödemelerle ilgili yaşanan olumsuzluklarda karşılıklı hoşgörü ile çözüme kavuşturulmaktadır (Emir, 2010). Ayrıca B2B kontratlar üzerinden gelen erken rezervasyonların yarısı kadar olan tutarlarının konaklamalardan aylar önce otellere 
acenteler tarafından ödenmesi de otel işletmelerinin ekonomik anlamda hareket kabiliyetlerini güçlendirmektedir.

\subsection{Turizm Sektöründe B2C (Business to Consumer) Ticaret Uygulamaları}

B2C model ticaret, özellikle internetin gelişmesiyle önemini katlayarak artırmaktadır. Bu modelde de otel ile online seyahat acenteleri (Online Travel Agency-OTA) arasında sözleşme yapılmaktadır. B2B'den farkı otel satış fiyatının tüketiciler tarafından görülerek satın alınabilmesidir. Ayrıca bu modelde OTA'lar satış fiyatı üzerinden \%10 ila \%25 oranlarında komisyon (Marj-in) düşerek uygulamaktadırlar. Oteller OTA'lar ile bir kez ıslak imzalı sözleşme yaparlar ve kendilerine OTA'lar tarafından kullanıcı adı ve șifre sağlanarak "Extranet" diye ifade edilen sunucularına erişim hakkı verilmektedir. İşletmeler kendileri bu sunuculara istedikleri zaman yedi gün yirmi dört saat erişerek tanıtım materyallerini, kontenjanlarını ve fiyatlarını güncelleyebilmektedirler (Çelebi, 2017). Aynı zamanda bu model, münferit olarak tatile çıkma isteğinde olan bireylerin ve son dakika rezervasyon yapan tüketicilerin daha çok tercih ettiği bir yapıda hizmetine başlamış olsa da günümüz rekabet koşullarında özellikle seyahat teknolojisindeki gelişmeler ışığında seyahat fiyatlamalarındaki rekabete dayalı uygun fiyat anlayışının hakim olduğu günümüz seyahat ve turizm pazarında büyük tur operatörlerini yakalayan bir model halini aldığı görülmektedir (Pırnar, 2005). B2C ticaretin otelcilikte tüketiciler nezdinde tercih edilmesinin sebeplerinden birisi de ödeme işlemlerinin B2B gibi rezervasyon aşamasında değil, konaklamada yapılabilmesi imkânı verebilmesidir. Son yıllarda çok önemli bir paya sahip olan B2C model turizm ticareti de işletmelerin geniş alanlarda varlığını gösterebilmesi adına B2B'de olduğu gibi yüksek önem taşımaktadır.

Potansiyel tüketicilerin satın alma ortamlarını için, B2C internet siteleri mümkün olduğunca sade, ifadeleri basit olmalı ve karmaşık olmamalıdır. Çünkü karmaşık yapılar tüketicinin korkabilmesine sebebiyet verebilmektedir (Çavuşoğlu, 2010). Tablo 3'te E-Ticaret dağıtım kanallarının B2C ticaret modelinde ürün sağlayıcılara, kurumlara ve tüketicilere sağladığı olanaklar yer almaktadır.

Tablo 3: B2C E-Ticaret Sitelerinin Ürün Sağlayıcılara, Kurumlara ve Müşterilere Sağladığı Avantajlar

\begin{tabular}{|c|c|c|}
\hline $\begin{array}{c}\text { Ürün } \\
\text { Sağlayıcılara }\end{array}$ & Kurumlara & Müşterilere \\
\hline $\begin{array}{l}\text { - Ödeme çeşitliliği } \\
\text { - Tahsilat güvencesi } \\
\text { - } 7 \text { gün } 24 \text { saat satış } \\
\text { olanağı } \\
\text { - Yeni bir satış ve } \\
\text { pazarlama kanalı }\end{array}$ & $\begin{array}{l}\text { - Ürün çeşitliliği } \\
\text { - Ödeme çeşitliliği } \\
\text { - Uygun fiyat } \\
\text { - Son dakika fırsatları } \\
\text { - Esneklik } \\
\text { - Güvenlik } \\
\text { - Görsel zenginlik } \\
\text { - Zengin içerik } \\
\text { - } 7 \text { gün } 24 \text { saat servis olanağı } \\
\text { - Bütçe yönetimi } \\
\text { - Standardizasyon } \\
\text { - Toplu satın alma } \\
\text { - Nakit yönetimi } \\
\text { - Gider tasarrufu } \\
\text { - Zaman tasarrufu }\end{array}$ & $\begin{array}{l}\text { - Çevrimiçi rezervasyon olanağı } \\
\text { - Turizm ile ilgili her türlü bilgi } \\
\text { sağlayabilme } \\
\text { - Ödeme çeşitliliği } \\
\text { - Ürün çeşitliliği } \\
\text { - Uygun fiyat } \\
\text { - Son dakika fırsatları } \\
\text { - Erken ödeme fırsatı } \\
\text { - Indirim fırsatı } \\
\text { - Kalite } \\
\text { - Esneklik } \\
\text { - Güvenlik } \\
\text { - Görsel zenginlik } \\
\text { - Zengin içerik } \\
\text { - } 7 \text { gün } 24 \text { saat servis olanağı }\end{array}$ \\
\hline
\end{tabular}

Kaynak: (KUTO, 2017) 


\subsection{Turizm Sektöründe C2B (Consumer to Business) Elektronik Ticaret Uygulamaları}

Tüketiciden-İşletmeye (C2B, Consumer to Business) elektronik ticaret yaklaşımı, turizm ticaretinde uygulanan yeni bir e-ticaret yöntemidir. Bu yöntemde tüketiciler, öneri ve tekliflerini turizm firmalarına ileterek e-ticaret faaliyeti oluşturmaktadırlar. Burada da teklif ve önerileri toplayarak ürün sağlayıcılara ileten aracı web sitelerinin günden güne önem kazandığı görülmektedir (Karamustafa ve Öz, 2008). Örneğin roomauction.com, primahotels.com, onlybidding.com gibi internet sitelerine rezervasyon ve istek bilgisini belirten münferit veya grup tüketicilerin bu talepleri, ilgili web siteleri aracılığıyla otellere iletilmektedir. Aynı anda karşılıklı iletişim sağlanabilen bu e-ticaret modelinde özellikle düşük turizm sezonlarında dolulukları arttırmada yarar sağlanabilmektedir. Başka bir örnekle, bir gıda firmasının çalışanlarını tatile göndermek için otellere konaklama tarihlerini ve bütçeleriyle birlikte konaklama şartlarını internet turizm acentelerine bildirerek C2B yönlü elektronik ticareti meydana getirir. Bu öneriyi kabul eden seyahat firmaları, gıda firmasına tekliflerini ileterek başlatılan $\mathrm{C} 2 \mathrm{~B}$ yönlü elektronik ticaretin oluşmasını sağlarlar (Çavuşoğlu, 2010). C2B ve B2C ticaret modellerinin her ikisini de uygulayan bir örnekle ele alırsak cultbay.com sitesi aracılığıyla otellerin odalarını ebay.com üzerinden açık arttırma usulüyle satışa sunmaları örnek gösterilebilir.

\subsection{Turizm Sektöründe C2C (Consumer to Consumer) Elektronik Ticaret Uygulaması}

Tüketiciden-Tüketiciye (C2C, Consumer to Consumer) elektronik ticaret uygulamasında tüketiciler kendi aralarında elektronik ortamda bir araya gelmekte ve ellerinde bulunan ürünleri alıp satabilmektedirler. C2C yönlü ticarette eksiksiz ve doğru bilgiyi elde etmek ve değerlendirebilmek oldukça zordur. Fakat bu yöntemin giderek gelişmesiyle birlikte kullanımı hızla artış göstermektedir (Saatcioğlu, 2005). C2C elektronik ticaret modelinin turizm boyutu konusunda seyahat sektöründe "Uber" ve konaklama sektöründe "AirBnb" internet siteleri gelmektedir. Tüketicilerin satın aldıkları elektronik ticaret hizmeti konusunda pozitif ya da negatif ürün yorumlarını ve deneyimlerini sosyal medya mecralarında karşılıklı paylaşması biçimi de C2C model ticaret içerisinde düşünülebilir. Tüketiciden tüketiciye e-ticaretin turizm sektöründe önde gelen web siteleri tripadvisor.com, holidaycheck.com, tophotels.ru gibi sağlayıcılardır. $\mathrm{Bu}$ uygulama turizm işletmelerinin kendileri hakkında tüketici geri bildirimi ve şikâyetlerini değerlendirerek potansiyel turistlere karşı yeni yollar geliştirme amacıyla kullanılsa da, bu model ticarette bulunan şeffaflık özelliği sayesinde rekabet ortamında işletmelerin kalitelerini yükseltebilmeleri amacıyla, ayırmış oldukları maliyet bütçelerini artırmaları yönünde stratejiler geliştirmelerini zorunlu kılabilmektedir. Fakat uzun zaman sürebilen ve pahalı olabilen pazarlama araştırmalarının C2C elektronik ticaret yöntemleriyle daha kolay ve daha ucuza yapılabilir hale gelmesi bu model elektronik ticaretin işletmeler için çok faydalı bir pazarlama politikası olduğunu göstermektedir (Bohur ve Kirali, 2015). Günümüzde bilginin üretimi, elde edilmesi ve yayılabilmesi yine veri temelli faaliyetlerin vazgeçilmezi olacağından, daha ilerili dönemde $\mathrm{C} 2 \mathrm{C}$ e-ticaret methodu, tüketicilerin turizm firmaları hakkındaki görüşlerini değerlendirecek olan istatistik firmalarının, bu verileri yine turizm şirketleri ve tedarikçilerine sunabilmesi şeklinde bir ticari yönteme dönüştüreceği belirgindir. C2C eticaretin işletmelere sağladığı olanakları, tüketicilerin kendi aralarında direkt ilişki kurmasını sağlaması ve turistlere işletmelerin ürünlerini sunmak için yeni bir iş oluşturma politikası sunması şeklinde özetlenebilir (Çavuşoğlu, 2010). 


\section{Oda Satışlarında Garantili Rezervasyon}

Oda satışlarında garantili rezervasyon konusu bir ailenin konaklama sürecinden örnek vererek ele alınabilir. İlgili aile otele giriş yapmadan odasının hazır edilmesi, yiyecekiçecek bölümlerinin yine bu aile için hazırlanması, mutfakta bu ailenin yemeğinin pişmesi ve otelde kaldıkları süre boyunca harcadıkları elektrik, su vb. tüketimlerinin ödemelerini otelciler genelde hiçbir ödeme almadan kendi kasalarından yapmaktadırlar. İşte burada B2B ticarette karşılıksız sadece güvene bağlı bir ticaret söz konusu olmaktadır ve ilgili gider kalemlerindeki peşin ödemelerinin karşılığını oteller acentelerden daha sonraki aylarda fatura karşılığı temin edebilmektedirler. Bu durumun otellerin kontratlarını yaparken acentelerin ödeme tarihlerini belirlemede daha titiz davranmalarının temel sebeplerinden birisini teşkil etmektedir. Ayrıca enflasyon ve paranın zaman değerinin düşmesi sebebiyle kontratların ülkemizde yabancı para birimi cinsinden yapılması tercih edilebilmektedir. Oteller tarafından yapılan tüm hazırlıkların maliyeti ortadayken, aktif rezervasyonların kullanılmamaları (No Show) oteller cephesinde gelirler üzerinde zarara yol açabilmektedir. İşte bu sebeple otellerin rezervasyonlarının güvenli ve garantili olmalarını her zaman tercih etmekten yana oldukları görülmektedir (Kethüda ve Faikoğlu, 2017). Erken rezervasyonlar (Early Booking) ve geri ödeme iadesi yapılamayan (Non-Refundable) rezervasyonlar garantili rezervasyonlar olduğu için otellerin önündeki belirsiz geleceği görmelerini kolaylaştırmaktadır. Özellikle erken ve iadesi yapılamayan rezervasyonlar için ödemelerin büyük bir kısmının konaklamadan aylar sonra yerine, aylar önce otellere yapılmakta olması ekonomik açıdan işletmeleri büyük oranda rahatlatmaktadır. Ayrıca sektörde etkin bir ticaret modeli olarak da görülmektedir. Günümüz otel işletmelerinin de mevcut satış kanallarında B2B ticaretin erken rezervasyonu ve B2C ticaretin iadesiz rezervasyonlarını kendilerine çekebilmek için rekabet halinde oldukları görülmektedir.

Otel işletmelerinin gelişen teknoloji ile ticarette daha net ve eşit rakamlarla çalışma isteklerinin arttığı belirlenmiştir (Demirciftci ve diğ, 2010). Günümüzde mevcut hemen hemen tüm konaklama tesislerinin kendilerine ait web sayfalarının olması ve bu sayfalara özellikle kendi iletişim bilgilerini belirtmeleri doğrudan rezervasyon alma isteklerinden kaynaklanmaktadır. Bilindiği üzere B2B ve B2C ticaret arasında başlayan fiyat savaşlarının en önemli mağdurlarından olan otelciler cephesinde, sürekli olarak booking.com ve expedia.com gibi dev B2C firmaların fiyat eşitsizliğini, sektörel adıyla "Rate Parity" sini öne sürerek otelleri ciddi anlamda uyarmaları baskı yaratsa da, farklı fiyatlarını takipte zorlanan otelciler tarafında bir nevi otokontrol sağlamaktadır. Buna bağlı olarak bir otelin fiyatının eşit olabilmesinin, rezervasyonun gerçekleşebilmesi yönüyle müşteri sadakati açısından (Demirciftci ve diğ., 2010) büyük yarar sağladığı görülmektedir. Oteller teknolojinin yararlarını keşfettikçe web sayfalarında uygulamalar kullanarak kendi müşterilerini düşük komisyon oranlarından ve e-ticarette özgürce hareket edebilmelerinden dolayı tercih etmektelerdir. CRS bilişim ürünü firmalarının yazılımları bu doğrultuda otellere çeşitli çözümler sunabilmektedirler (Unurlu, 2010). Bu çözümlerin başında kendi web sayfalarında profesyonelce rezervasyon almalarını sağlayan rezervasyon motoru gelmektedir. Bu üründe oteller, fiyatlarını ve müsaitliğini kendisine yazılım firmasından temin edilen çevrimiçi panele yüklemektedirler. Bu panel genelde "Extranet" ismiyle kullanılmaktadır. Extranete yüklenen güncel fiyat ve müsaitlik bilgisine erişim, işletmenin kendi web sitesinin ana sayfasında ziyaretçilerinin görebileceği bölgeye yerleştirir. Bazı büyük zincir otellerin sadece bu bölge seçimi için bile büyük Ar-Ge çalışmaları yaptığı bilinmektedir (Bemile ve diğ., 2014). Çünkü doğrudan tüketiciye ulaşacakları bu bölüm tüketiciyi yakaladıkları ve kaybetmek istemedikleri andır, mümkün olduğunca sade ve anlaşılır bir dille rezervasyon sürecini en aza indirgeyerek, kafa karışıklığına mahal vermeden kişilerin odaları satın alabilmesini sağlamak (Çavuşoğlu, 2010), hem otelcilerin hem de CRS'i sağlayan 
yazılım firmalarının ortak başarısı olacaktır. Ortak başarı bu firmalarla yapılan anlaşma şartlarında kendisini daha çok göstermektedir. Eğer otelci CRS firmasıyla yıllık düzenli bir ödeme üzerinden anlaşma sağlar ise ortak başarı sadece tesadüflere kalabilmektedir. Fakat otelci iyi bir pazarlıkla yıllık ödeme yerine kendi web sitesi rezervasyonları için rezervasyon başına düşük komisyon üzerinden anlaşma sağlayabilirse artık satışlardan komisyon alan CRS firması da tüm bilgi ve deneyimini otelin kendi web sitesinin satışlarının artmasını sağlayacağı bir hedefte sürdürebilir. Böylelikle gelişmiş bir deneyim ve donanıma sahip olan bu yazılım firmaları kendi gelirlerini de artırmak için arama motorlarında (google, yahoo, yandex, bing gibi) farklı kelime çalışmaları yaparak internet üzerinde otelin görünürlüğünü arttırmada etkin rol oynayacaklardır. Ayrıca bu yazılım firmaları tercih edilirken dikkat edilecek diğer husus sundukları istatistikler olmaktadır. Otelciler bu istatistiklerde çok hayati satış deneyimleri verilerini kolaylıkla elde edebilmektedir. Bu verilerin ışığında otelcilerin hangi tarihler arasında hangi oda tiplerine bakıldığını, kaç kişilik konaklamaların hangi ülkelerden aratıldığına kadar tüm bilgileri görerek hem fiyatlamada hem de tahminlemede karar almayı kolay hale getirdikleri söylenebilir. Otelcilerin bu hizmetleri sunabilen bir CRS firmasıyla anlaşması bu sebeple önemlidir. Büyük zincir otel işletmelerinin pazarlama bütçelerine bağlı olarak kendi içlerinde kendilerine özgü rezervasyon sistemleri kurdukları bilinmektedir (Demirciftci ve diğ., 2010). Diğer oteller ise bu sistem intiyaçlarını bağımsız CRS danışman firmalarıyla karşılayabilmektedirler.

Tüketicilerin işletmelere ulaşabilmesinden daha önem arz eden konu nasıl ulaştıklarıdır. Turizm tüketicilerinin tatil tercihinde kullandıkları internet sağlayıcıları aşağıda Tablo 4'te belirtilmiştir.

Tablo 4: Tüketicilerin tatil tercihinde kullandıkları internet sağlayıcıları

Google

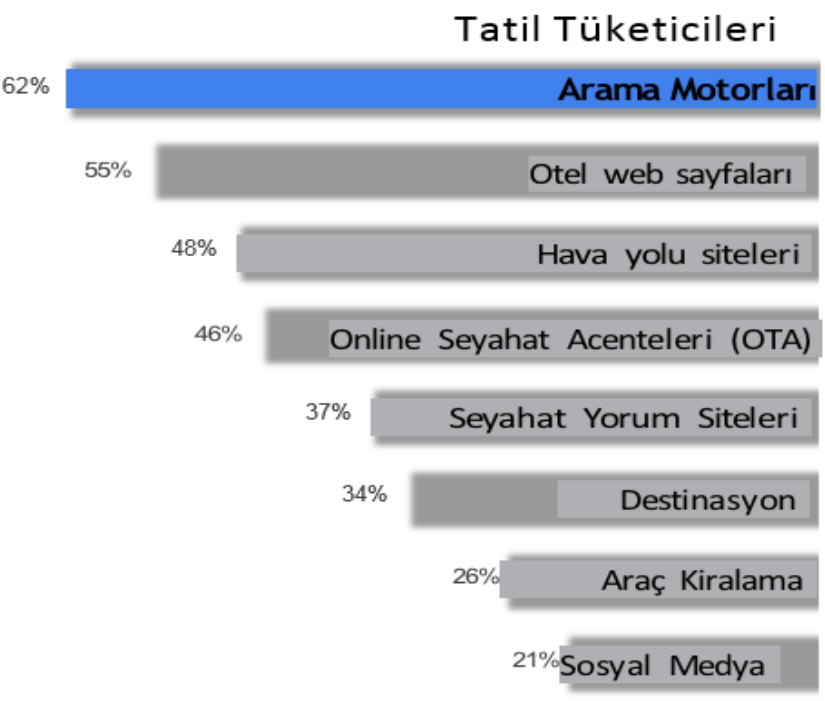

Şirket Tüketicileri

Otel web sayfaları $69 \%$

$\begin{array}{ll}\text { Hava yolu siteleri } & 62 \%\end{array}$

Arama Motorları $\quad 54 \%$

Online Seyahat Acenteleri (OTA) 52\%

Araç Kiralama Siteleri $\quad 48 \%$

Seyahat Yorum Siteleri $\quad 39 \%$

Destinasyon $\quad 31 \%$

Sosyal Medya $\quad 25 \%$

Source: The Traveler's Road to Decision, Google and Ipsos MediaCT. July 2012.

Kaynak: (The Traveler, 2012) 
Yukarıdaki tabloda Google araştırma biriminin 2012 yılında 5000 Amerikalı tüketici üzerinde Nisan ve Mayıs ayları süresince seyahat kararlarında kullandığı internet sağlayıcılarından yararlandıkları dağılım gösterilmektedir. Tabloda da görüldüğü üzere tatil ve iş seyahatine çıkan tüketicilerin en çok kullandıkları sağlayıcılar arasında arama motorları ve otel web sayfaları gelmektedir. Ayrıca oteller profesyonelce hazırladıkları web sayfalarında sosyal medya linklerini de tüketicilere sunmaları önem arz etmektedir. Bu durum otellerin ürün güvenirlikleri açısından önem arz etmektedir.

E-ticarette rekabetin sınırları her geçen gün artmakta ve şeffaflık olgusu işletmeleri bir adım öteye taşımaktadır. Dünyanın önde gelen sosyal medya yorum sitelerinin (tripadvisor.com, holidaycheck.com, facebook.com gibi) logolarını otel işletmelerinin web sayfalarında aktif kısa yol linkleriyle gösterebilme cesaretleri kendi web sayfalarından rezervasyonlarını artıracağı gibi rakiplerine oranla üstünlük sağlamalarını da sağlayacaktır. Fakat burada önemli bir husus CRS firmalarının da sağlayabildiği bir ürün olan itibar yöneticisini (review pro, trust you vb.) kullanmaları veya kendi yazılımlarıyla başka bir siteye yönlendirme yapmadan ilgili sitelerdeki sadece yorum bilgilerini web sayfası ziyaretçilerine sunmaları gerektiğidir. Çünkü oteller sosyal medya linklerini doğrudan kendi web sayfasında ilan ederse, bu sitelere yorumları okuma amacıyla giriş yapan müşterilerini yine yorum sitesinin ortaklık kurduğu diğer acentelere yönlendirebilme intimali söz konusu olabilmektedir. Bununla beraber ilgili kayıplar oteller tarafından tespit edilememektedir. Burada kendi web sitesinde sunmuş olduğu fiyatlar ile diğer online seyahat acenteleri kanallarında sunduğu fiyatların eşit olması, hatta kendi web sayfasındaki bu eşit fiyatlara dönemine göre özel hizmetlerinden ücretsiz ilaveler yaparak albenisini yükseltebilmesi otellerin kendi satışlarını arttırabilmektedir. Ayrıca profesyonel yorum takip sistemleri, otelcilere kendilerinin ve rakiplerinin güncel yorumlarını anlık bildirimler yaparak, rekabet ortamında dinamik bir atmosfer yaratabilmelerine ve rakiplerinin stratejilerini takip edebilmelerine olanak verebilmektedir.

\section{Kanal Yöneticisi (Channel Manager)}

Otellerin bilişim ürünü olan CRS yazılımlarının sunduğu hizmetlerin başında kanal yöneticisi gelmektedir. Kanal yöneticisi yazılımları, işletmelere online seyahat acentelerinin extranetlerine aktif olarak tek panelden, hızlı bir şekilde erişebilme olanağı kazandırarak, önemli ölçüde zaman kazandırmaktadır (Demirciftci ve diğ., 2010). İşletmelerin çevrimiçi dağıtımını yaptığı satış kanalları aşağıda şekil 1'de belirtilmiştir.

\section{Şekil 1: Otel Kanal Yöneticisiyle Dağıtım Şeması}
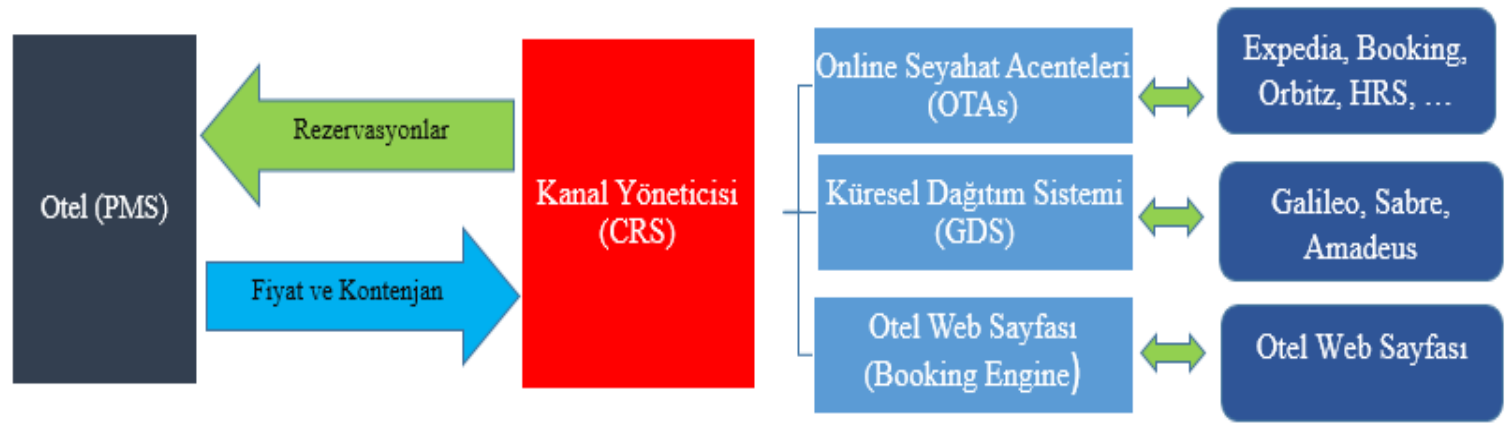

Kaynak: (Kaya, 2017) 
Otelin tüm fiyat ve kontenjanının CRS sistemi üzerinden tüm çevrimiçi sistemlere dağıtımını sağlayan kanal yöneticisinde, otel yetkilisi sadece tek panel üzerinden CRS'e gerekli fiyat ve kontenjan verilerini tanımlamaktadır. Bu veriler CRS merkezi üzerinden, daha önceden tanımlanarak bağlantıları yapılmış tüm çevrimiçi sistemlere gönderilmektedir. Bu sistemler OTA'lar, GDS'ler (Global Dağıtım Sistemi) ve otelin kendi web sayfasından oluşmaktadır. Oteller bu dağıtım sistemi sayesinde kendi web sayfaları dahil tüm B2C satış kanallarında eşit fiyat ile satışa çıkabilme olanağı sağlarken, değişen şartlarda kolaylıkla fiyatlarını güncelleyebilmektedirler. Son yıllarda B2B satış kanallarının da otel satışlarında fiyat eşitliği ilkesine sadık olma stratejileri ile otellere satış fiyatlarını extranetler üzerinden belirleyebilmelerine olanak sağlamaktadır. Böylelikle oteller kanal yöneticileri üzerinden B2B fiyatlarının da kontrolünü sağlayabilmektedirler. Ayrıca mobil uygulamalar ve platformlar ile sürekli erişime açık olan bu sistemleri diledikleri zaman ve yerden kontrol edebilmektelerdir (Şengonca ve diğ., 2017). Özellikle teknolojinin beraberinde sunduğu rekabet ortamında OTA'lar içerisindeki teknik ve taktiksel yaklaşımları lehine çevirmek isteyen otelciler bu platformların hemen hepsinde yer alarak hem görünürlüklerini arttırmış olurlar hem de bu yüksek sayıdaki OTA'ları kolaylıkla aynı anda kontrol edebilme olanağı bulmaktadırlar.

\section{Dinamik Fiyatlamalı Oda Satışlarında Kullanılan Terimler}

Günümüz otelcilik gelir yönetimi fiyatlamasında kullanılan bazı yeni terimleri ve kısaltmalarını tanımlamamız önem arz etmektedir. Bu terimlere aşağıdaki tablo 5 'te yer verilmiştir.

Tablo 5: Otellerde Gelir Yönetimi Fiyatlamasında Uygulanan Terim ve Kısaltmalar

\begin{tabular}{|l|l|}
\hline Terim & Tanımı \\
\hline BAR (Best Available Rate) & İlgili tarih için oteldeki satılabilir en iyi fiyat \\
\hline ADR (Avarage Daily Rate) & Ortalama oda Fiyatı \\
\hline REV (Revenue) & Toplam gelir \\
\hline OCC (Occupancy) & Toplam doluluk \\
\hline REVPAR (Revenue Per Available Room) & Oda başına düşen gelir \\
\hline COMPSET (Competitive Set) & Rakip oteller \\
\hline
\end{tabular}

Kaynak: (Hyunh, 2018)

Tablo 5 'ten de anlaşılacağı üzere "otelcilik ürün fiyatı" konusu detaylı, dinamik ve etkin bir yapıya sahip olmaktadır. En iyi fiyatın, doluluğa bağlı olarak artıp azalan fiyat dalgalanmaları içerisindeki otelin kapasitesine bağlı ve o esnada gerçekleşmiş toplam satış içindeki tüm müşteriler arasından ürünü en uygun fiyatla (BAR) elde eden müşterinin fiyatı olduğu görülmektedir. Yine o esna dediğimiz zaman aralığına odaklanılırsa satışın gerçekleştiği günün toplam hasılatı, işletmenin toplam geliri (REV) olmaktadır. Yine aynı zaman aralığındaki toplam geliri oda sayısına oranladığımızda ise toplam satışlar içerisindeki ortalama oda gelirini (REVPAR) bulmuş oluruz. İlgili zaman için yapılan satışlar toplam doluluğumuzu (OCC) gösterirken, belirli dönemler arasındaki toplam gelirin toplam satılabilir oda sayısına bölümüyle de ortalama oda fiyatı (ADR) belirlenmektedir. Ayrıca fiyat oluşturmada etkili olan rakiplerin çevrimiçi durumları ve fiyatları (COMPSET), kısa ve uzun vadeli etkin fiyat değişim kararlarında büyük bir öneme sahiptir (Ivanov, 2014). 


\section{Maksimum Doluluk}

Otellerin doluluklarına göre fiyatlama yapabilmeleri verimli bir gelir yönetimi açısından büyük önem taşımaktadır. Aşağıda şekil 2'de örnek bir otelin aylık doluluk grafiği yer almaktadır. 
Şekil 2: İstanbul Hotel Eylül ayı doluluk grafiği

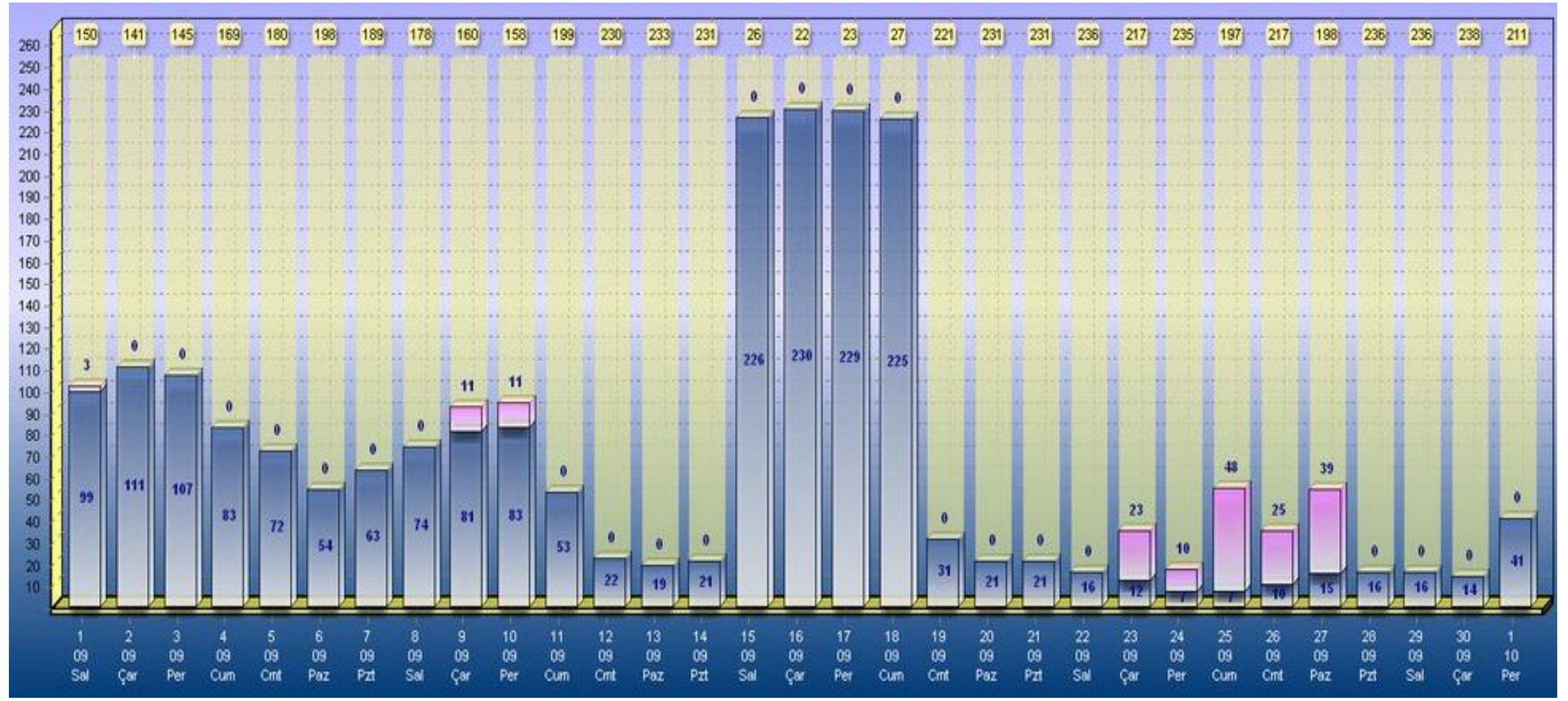

Kaynak: (Elektra, 2017) 
Yukarıdaki grafik üzerindeki 15 ve 19 Eylül tarih aralığına Temmuz ayından baktığımızı varsayalım. Önümüzdeki süreçte 15-16-17-18 Eylül tarihlerinin diğer tüm günlerden önce dolacağını tahmin etmemiz gerekmektedir. Burada operasyonel anlamda ilgili tarihlerde müsait kalan oda sayısı, grubun tarihinin öncesi ve sonrasındaki günlerin satışının zora girerek boş odaların oluşacak olması gibi çeşitli faktörlerin, grup rezervasyon aşamasında grubun fiyatıyla kıyaslanarak ilgili grup rezervasyonunun onaya alınmış olması gerekmektedir. Etkin verimli bir fiyatlama yönteminin bu noktada ortaya çıktığı görülmektedir. Özellikle örnekteki kapasitesi dolmak üzere olan otelin ilgili dört gününün fiyatı B2C kanallarda mevcut fiyatının üzerine çıkarılabilir, hemen öncesindeki ve sonrasındaki tarihlerden normal fiyatlara oranla indirim yapılabilir. Buna bağlı olarak doluluğu yüksek ve düşük günlerin birbirini karşılayabilmeleri sağlanabilmelidir. Ayrıca B2B kanallarda düşük fiyata sahip oda tiplerinin satışa kapatılarak ve konaklamalara minimum kalış süresi ilave edilerek yüksek fiyatlı oda tiplerinin ilgili dört günü de kapsayacak şekilde gerçekleşebilmesi sağlanabilir.

Otel işletmeleri normal şartlar altında hiçbir zaman tam doluluğa ulaşamamaktalardır (MEGEP, 2013). Ancak aşırı doluluk yoluyla tam doluluğa hatta daha fazlasına erişebilmektedirler. Fakat bu durum beraberinde reklamasyonlar ve internette şikayetler gibi önemli cezalara sebebiyet vererek otelin daha sonrasında gelir ve prestij kaybına yol açabilmektedir (Hwang veWen, 2009). Bunun yerine verimli ve etkin fiyat stratejisi uygulayan işletmeler doluluklarını en iyi fiyatlar (RevPAR) ile sağlayabildiklerinden hizmet kalitelerinden ödün vermeden daha yüksek gelir elde edebilmektedirler. Otellerin fiyat stratejisini genişleyen teknoloji yelpazesiyle zamanı etkin kullanarak kontrol altında tutabilmeleri açısından kanal yöneticisinin yararlı olduğu görülmektedir.

\section{Sonuç ve Öneriler}

Oteller doluluk grafiklerinde karşılaşılan boşlukları etkin bir biçimde doldurabilmek için anlık müdahaleler ile kanal yöneticisi kullanarak kontrol edebilmektedirler (Kannan ve Praveen, 2014). Günümüz şartlarında satış pazarlama yöneticilerinin dinamik fiyatlama ve sürekli rakiplerini takip edebilecek yeterli zamanı bulabilmeleri süreklilik arz edememektedir. Bu doğrultuda işlerini kolaylaştırabilecekleri yazılımlara intiyaç duymaktadırlar. İşletmelerin bu tür verim getirisine yaptıkları yazılım yatırımlarının maliyetleri kendilerine kısa sürelerde geri dönebilmektedir. Aslında online seyahat acenteleri üzerinden yüksek komisyonlu rezervasyonların toplam hacmi ele alındığında bu hacmin küçük bir kısmının bile CRS ürünü olan rezervasyon motoru sistemiyle kendi web sitesinden geliyor olması, OTA'lara oranla, tek haneli komisyon oranlarına düştüğünden çok kısa sürede CRS sisteminin maliyetini karşılayabileceği ön görülmektedir. Burada otellerin kaliteli ve özgün web sayfaları oluşturabilmeleri başarılarını artırabilmelerinin yanında, tüm mobil cihazlarla uyumlu uygulamalar ve ara yüzler oluşturmaları rekabet yarışında kendilerini bir adım öteye taşıyabilecekleri anlamına gelmektedir (Murphy ve diğ., 2016). Diğer bir hususta "Sanatkar yaparken, tüccar alırken kazanır." deyimiyle otel yönetiminin yazılım firmasından CRS ve diğer ürünler için işletmenin ayırdığı bütçesini etkin planlamalı ve intiyaçlarını karşılama noktasında kararlarını verimli oluşturabilmelidir.

Otel işletmelerinin önemli sorunlarından olan doğru fiyat ve doğru zaman konusunda literatürdeki verilerin incelenerek, elde edilen bilgiler ışığında uygulamalarda ne tür problemler oluştuğunu tespit etmek için ve bunlara ne tür çözümler getirilebileceğine dair yapılan bu incelemede, otellerin fiyat belirlerken dikkat etmesi gerekenlerin başında, takvimlerinde yer alan özel gün ve haftalara dikkat 
ederek fiyatlamalar yapmaları gerektiği belirlenmiştir. Ayrıca tam doluluk sebebiyle satışa daha önceden kapatılmış otellerin özellikle son dakikalarda yaşanan iptal durumlarında tekrardan dağıtım kanallarında kontenjan açabilmeleri açısından kanal yöneticileri etkin çözümler yaratabilmektedir. Bu doğrultuda otel işletmelerinin oda fiyatlandırmada verim yönetimi açısından kanal yöneticisi kullanmaları önerilir. Literatürde kanal yöneticisi kullanan işletmeler ile ilgili çalışmalar çok az sayıdadır. Bu çalışma ileride CRS ürün ve hizmetleri konusunda araştırmaların yapılabilmesine örnek teşkil etmesi açısından önem taşımaktadır.

Teknolojinin hızlanarak hayatı kolaylaştırmasıyla turizm endüstrisinin aynı oranda etkilenerek turizm işletmelerinin operasyonel faaliyetlerinde bilgisayar yazılımlarının her geçen gün daha da önemini arttıracağı ortadadır (Bilgin, 2017). Otel işletmelerinin oluşan turizm pastasından verimli bir şekilde yararlanabilmesini sağlayan otelcilik yazılımları da günden güne gelişerek ihtiyaçlara cevap verebilmeleri bu yazılımlarla sağlanabilmektedir (Korzh ve Onyshchuk, 2018). Ayrıca kanal yöneticisini kendi otelcilik programına (PMS) entegre ederek otomatik olarak fiyat değişimleri kullanan işletmeler üzerinde nitel araştırma tekniklerinden görüşme yöntemi kullanılarak, verim yönetimiyle ilgili bir başka çalışma konusu araştırılabilir. Kanal yöneticisinin sunduğu merkezi rezervasyon ağı sayesinde, rezervasyon iletişiminin tek merkezde toplanabilmesi de, daha sağlıklı bir rezervasyon ağ sistemi yapısının oluşmasını sağlamaktadır.

Otellerin hareket kabiliyetlerini genişleterek B2C fiyatlara mobil uygularla birlikte diledikleri zaman müdahale edebilmelerini sağlayan kanal yöneticisi ile verimli satışlar gerçekleştirerek, doluluklarını maksimum seviyeye etkin fiyatlarla çıkarabilmelerinin mümkün olduğu görülebilmektedir. Her zaman erişeme açık olan kanal yöneticisiyle dolmak üzere olan günler daha yüksek fiyatla satılabilirken, doluluğu düşük günlerde daha uygun fiyatlar oluşturularak genel doluluk, dengeli, etkin ve dinamik fiyatlarla sağlanabilmektedir. Ayrıca otellerin B2C kanallardaki afişe fiyatlarını güncel olarak takip edebilmeleri hem tüketiciler hem de paydaşlar açısından önem arz etmektedir. Bu doğrultuda otellerin hotelscombined.com, hotelcomparison.com, trivago.com, kayak.com gibi fiyat kıyaslaması yapan web sayfalarını sürekli kontrol etmeleri gereklidir. Böylelikle otellerin OTA'lar ile ilişkilerini güvenilir tutmaları konusunda ve eşit fiyat ile müşteri sadakati oluşturabilmesi yönünde, otellere B2B fiyatlarını B2C'ye afişe eden firmaları tespit edebilmeleri yönünde yarar sağlayabilir.

\section{Kaynakça}

Altunışık, R. (2009). Turizm İşletmelerinde Pazarlamanın Temelleri ve Iki Farklı Pencereden Pazarlama Yöntemi: Üretici ve Tüketici Bakış Açısı. Değişim Yayınları.

Ansen, E. N., ve Fırat, A. (2009). Turizm İşletmelerinde Elektronik Pazarlama: Antalya "A Grubu Seyahat Acentaları" Örneği. Girişimcilik ve Kalkınma Dergisi, 4(2), 117-134.

Ateş, U., ve Boz, M. (2015, Ekim 14). Konaklama Işsletmelerinin Web Sitelerinin Değerlendirilmesi: Çanakkale Örneği. Research Gate: https://www.researchgate.net/publication/312472581 adresinden alındı

Badem, C., ve Fırat, D. (2011). Temel Pazarlama Bileşenleri Açısından Muhasebe Verilerinin Kullanılması: Pazarlama Muhasebesi. Kocaeli Üniversitesi Sosyal Bilimler Enstitüsü Dergisi, 21(1), 77-101.

Bayram, M., ve Yaylı, A. (2009). Otel Web Sitelerinin İçerik Analizi Yöntemiyle Değerlendirilmesi. Elektronik Sosyal Bilimler Dergisi, 8(27), 347-379. 
Bemile, R., Achampong, A., ve Danquah, E. (2014). Online Hotel Reservation System. International Journal of Innovative Science, Engineering \& Technology, 583-588.

Bilgin, Y. (2017). Bir Destinasyondaki Otel İşletmeleri arasında işbirlikçi pazarlama uygulanabilir mi? Bolu otellerinde bir araştırma. AiBÜ Sosyal Bilimler Enstitüsü Dergisi, 17(2), 105-132.

Binbay, M. (2007, 11 14). Otel İşletmelerinde Pazarlama Stratejileri. Yüksek Lisans Projesi. Kahramanmaraş: Kahramanmaraş Sütçü İmam Üniversitesi, Sosyal Bilimler Enstitüsü.

Bohur, E., ve Eryılmaz Kirali, A. (2015, June 4-5). Küreselleşme ve Teknolojinin Turizm Sektörü Pazarlama Faaliyetleri ve Satış Kanallarındaki Etkisi. PressAcademia Procedia-Global Business Research Congress, 81-93.

Boylu, Y., ve Tuncer, A. (2008). Konaklama İşletmelerinin Yönetim Yapılarının Web Tabanlı Pazarlama Faaliyetlerine Etkisi Üzerine Bir Araştırma. İstanbul Ticaret Üniversitesi Sosyal Bilimler Dergisi, 1(13), 11-30.

Breffini, M. N., Cathy, A. E., ve Glassmire, J. (2017). Total Hotel Revenue Management: A Strategic Profit Perspective. Cornell Hospitality Report, 17(8), 315.

Christodoulidou, N., Brewer, P., Feinstein, A., ve Bai, B. (2007). Electronic Channels Of Distrubition: Challenges Solutions For Hotel Operators. Hospitality Review, 25(2), 92-100.

Chu, R. (2001). What Online Hong Kong Travelers Look for on Airline / Travel Websites? Hospitality Management(20), 95-100.

Çavuşoğlu, M. (2010). Konaklama İşletmelerinde Elektronik Ticaret Kullanımı: Gökçeada ve Bozcaada'da Bir Araştırma. Girişimcilik ve Kalkınma Dergisi, 5(2), 111-142.

Çelebi, N. A. (2017, 11 27). Verim Yönetimi. Turizm Güncel: http://turizmguncel.com/makale/yield-management--verim-yonetimi-m809.html adresinden alındı

Çıvak, B. (2016). Otel İşletmelerinde Getiri Yönetimi ile Online Kanal Yönetimi ve Teknolojilrinin Etkileşimi,. Yüksek Lisans Tezi. Eskişehir: Anadolu Üniversitesi Sosyal Bilimler Enstitüsü Turizm İşletmeciliği Anabilim Dalı.

Çıvak, B., Kaya, E., ve Emeksiz, M. (2017). Online Distrubution Channels and Yield Management In The Hotel Industry. D. Gürsoy içinde, Routledge Handbook of Hospitality Marketing (s. 17. Bölüm). Routledge.

Demirciftci, T., Cobanoglu, C., Beldona, S., \& Cummings, P. (2010). Room Rate Parity Analysis Across Different Hotel Distribution Channels in the U.S. Journal of Hospitality Marketing \& Management, 4(19), 295-308.

Demirtaş, N. (2010). Otel İşletmeciliği (2. Baskı b.). Ankara: Ankara Üniversitesi Uzaktan Eğitim Yayınları.

Elektra. (2017, 11 28). Destek Elektra: http://www.destekelektra.com/elektrav4/default.asp?mdl=grafikler\&cat=10 adresinden alındı

Emir, O. (2010). Otel İşletmelerinin Pazarlanmasında Seyahat Acentalarının Rolü: Otel İşletmeleri Tarafından Bir Değerlendirme. Ege Akademik Bakış, 10(4), 12451256.

Erdem, Ş. (2007). Sağlık Hizmetleri Pazarlaması:Hastaların Sunulan Hizmetin Kalitesini Algılamaları Üzerine Bir Uygulama. Yüksek Lisans Tezi. Trakya Üniversitesi Sosyal Bilimler Enstitüsü.

Global Report. (2016). Trip Advisor: https://www.tripadvisor.com/TripAdvisorlnsights/w665 erişim tarihi: 02.12.2018 adresinden alındı

Gürçaylılar Yenidoğan, T., \& Yenidoğan, A. (2013). Sözleşme Tasarımı: Tur Operatörü-Otel Kontenjan Sözleşmeleri. Ege Akademik Bakış, 13(3), 393-403. 
Gürel, A., \& Kayar, Y. (2017, 11 28). Gelir Yönetiminin Hizmet Sektöründeki Yeri. Aydın Üniversitesi: http://abmyod.aydin.edu.tr/makaleler/sayi_44/geliryonetiminin-hizmet-sektorundeki-yeri.pdf adresinden alındı

Hwang, J., \& Wen, L. (2009). International Journal of Contemporary Hospitality Management. The effect of perceived fairness toward hotel overbooking and compensation practices on customer loyalty, 21(6), 659-675.

Hyunh, N. (2018, May). Revenue Management for Small an Independent Hotel: An Action Plan for P Hotel. Degree Programme in Restaurant Entrepreneurship Bachelor's Thesis, 24.

Ivanov, S. (2014). Hotel Revenue Management From Theory To Practice. Bulgaristan: Zangador Yayıncılık.

Kannan, P. K., ve Praveen, K. K. (2014). Dynamic Pricing on the Internet: Importance and Implications for Consumer Behavior. International Journal of Electronic Commerce, 5(3), 63-83.

Karamustafa, K., ve Öz, M. (2008). Uluslararası Turizm Dağıtım Kanalı Değer Zincirine Internetin Katkısı: Fırsatlar Ve Tehditlere Dayalı Bir Değerlendirme. Dumlupınar Üniversitesi Sosyal Bilimler Dergisi(21), 273-293.

Kaya, E. (2017, 11 23). Doğru Yield Management için Forecasting ve Fiyatlandırma. Linked In: https://www.linkedin.com/pulse/20141014213651-65471753do\%C4\%9Fru-yield-management-i\%C3\%A7in-forecasting-vefiyatland\%C4\%B1rma?trk=mp-reader-card adresinden alındı

Kethüda, Ö., ve Faikoğlu, S. (2017). Dağıtım Kanalı Türlerinin Otellerin Cirosuna ve Doluluk Oranına Etkisinin Değerlendirilmesi: Akçakoca'da Bir Araştırma. Bartın Üniversitesi i.I.B.F. Dergisi, 8(15), 203-224.

Korzh, N., ve Onyshchuk, N. (2018). Selection Of The Optimal Set Of Revenue Management Tools In Hotels. Technology Audit and Production Reserves, 14(39), 16-21.

KUTO. (2017, 11 27). Kuşadası Ticaret Odası E-Ticaret ve Turizm Sektörü: http://www.kuto.org.tr/img/kuto/raporlar/04.pdf adresinden alındı

Linkage, H. (2017, 12 20). Channel Manager Nedir ? Academy Hotel Linkage: https://academy.hotellinkage.com/channel-manager-nedir-4e3702d0b7d adresinden alındı

MEGEP. (2013, 11 27). Konaklama ve Seyahat Hizmetleri Rezervasyon Durum Analizleri.

İsmek: http://ismek.ist/files/ismekOrg/file/2013_hbo_program_modulleri/RezervasyonDu rumAnalizleri.pdf adresinden alındı

Meterrelliyöz, M., ve Tan, A. (2014). Gelir Yönetimi Metodlarının Türkiye Otelcilik Sektörüne Uygulanması. Gazi Üniversitesi Iktisadi ve Idari Bilimler Fakültesi Dergisi, 16(3), 85-110.

Murat, G., ve Çelik, N. (2007). Analitik Hiyerarşi Süreci Yöntemi İle Otel İşletmelerinde Hizmet Kalitesini Değerlendirme: Bartın Örneği. ZKÜ Sosyal Bilimler Dergisi, 3(6), 1-20.

Murphy, H., Chen, M., ve Cossutta, M. (2016). An investigation of multiple devices and information sources used in the hotel booking process. Tourism Management $52,44-51$.

Öncüer, M. E., ve Yılmaz, B. S. (2009, 09 04). Bilgi Ekonomisinin Turizm Endüstrisinde Yol http://www.bilgiyonetimi.org/cm/pages/mkl_gos.php?nt=227 adresinden alındı

Öndoğan, E. N. (2017, 11 23). Restoran Pazarlamasında Kullanılan Temel Pazarlama Karma Elemanları " $P$ ". Dergi Park: http://dergipark.ulakbim.gov.tr/esam/article/viewFile/5000127175/5000116881 adresinden alındı 
Özdemir, G. B. (2011). Paket Tur Sözleşmesinde Taraflar ve Tarafların Borçları ve Hakları. Sosyal Bilimler Dergisi(2), 68-74.

Özdipçiner, N. S. (2010). Turizmde Eloktronik Pazarlama. Internet Uygulamaları ve Yönetimi Dergisi, 1(1), 5-22.

Öztürk, N. (2017, 12 20). Turizm işletmelerinde $7 P$ ve $7 C$. Prezi.com: https://prezi.com/dvmkhwzghvnm/turizm-isletmelerinde-7p-ve-7c/ adresinden alındı

Pırnar, İ. (2005). Turizm Endüstrisinde E- Ticaret. Ekonomik ve Sosyal Araştırmalar Dergisi(1), 28-55.

Roland, S., Stangl, B., Fux, M., ve Inversini, A. (2013). Distribution channels and management in the Swiss hotel sector. Information and Communication Technologies in Tourism 2013, 554-565.

Saatcioğlu, C. (2005). Yeni Ekonomi ve Finansal Piyasalar Üzerine Etkisi. Iktisadi ve Idari Bilimler Dergisi, 19(1), 151-165.

Sarışık, M., ve Akova, O. (2006). Seyahat Acentalarında İnternetin Rolü ve Önemi Üzerine Bir Araştırma. Kocaeli Üniversitesi Sosyal Bilimler Enstitüsü Dergisi, 12(2), 128-148.

Şengonca, H., Kızıldağ, Ç., \& Yöndem, C. (2017, 11 27). B2C Elektronik Ticaret Uygulamalarında Mobile Agent Teknolojisinin Kullanımı. Emo Org Tr: http://www.emo.org.tr/ekler/797fob27eeacdec_ek.doc adresinden alındı

The Traveler. (2012, $\quad \overline{11}$ 29). Google: https://www.google.com.tr/search?q=google+ipsos+mediact+august+2012\&oq= google+ipsos+mediact+august+2012\&aqs=chrome..69i57j69i64.42999j0j7\&sour ceid=chrome\&ie=UTF-8 adresinden alındı

Unurlu, Ç. (2010). Otel İşletmelerinin Odalar Bölümünde Gelir Yönetimi: İstanbul'daki 5 Yıldızlı Otelllerde Bir Uygulama. Trakya Üniversitesi Sosyal Bilimler Enstitüsü İşletme Anabilimdali Yüksek Lisans Tezi: http://193.255.140.91/jspui/bitstream/1/1662/1/0087759.pdf adresinden alındı

Yakut Aymankuy, Ş. (2001). Turizm Sektöründe Kriz Yönetimi. Balıkesir Üniversitesi Sosyal Bilimler Dergisi(6), 105-118.

Yıldız, S., ve Yıldız, Z. (2015). Bilişim Teknolojilerinin Turizm Pazarlaması, Dağıtım Sistemi ve Seyahat Acentelerinin İş Modeli Değişimine Etkisi. Insan ve Toplum Bilimleri Araştırmaları Dergisi, 4(3), 595-611.

Yıldıztekin, İ. (2009). Konaklama Hizmetlerinde Maliyete Dayalı Fiyatlama ve Fiyat Değişiminin Bölüm Karlıı̆ına Etkileri. Atatürk Üniversitesi İktisadi ve Idari Bilimler Dergisi, 23(4), 215-238. 